\title{
Is There Recovery After Fire, Drought, and Overgrazing?
}

\section{Can Mojave Desert rangeland recover after natural events, like fire and drought, and years of heavy grazing? Can rest-rotation grazing or rest from grazing allow perennial grass and browse to recover?}

\author{
By Lee E. Hughes
}

$\mathrm{O}$ ne of the rangeland manager's greatest challenges is to manage the range so that plant communities recover from human impacts. After fire, heavy grazing, and drought, it is slow and frustrating when trying to bring arid environment plant communities back to a state of diverse perennial plants (instead of solely annuals) with all their former grasses, forbs, shrubs, and browse. In 1990 , a drought revealed over utilization problems in three pastures of two mojave desert allotments - the Pakoon Springs(Big Hole and Wayne's Well pastures) and Cottonwood (Lower Cottonwood Wash pasture). After consultations and coordination, managers of each allotment took a different long-term solution to restore the vegetation to a more diverse perennial species composition than existed after fire, drought and overgrazing in 1990.

Cottonwood allotment went on a rest-ro- tation grazing system and Pakoon Springs took total rest from grazing. After 10 years of monitoring studies on each pasture under the chosen management, the opportunity arose to see if rest from grazing or rest-rotation grazing offered any evidence of increasing perennial vegetation. Recovery of perennial species in the

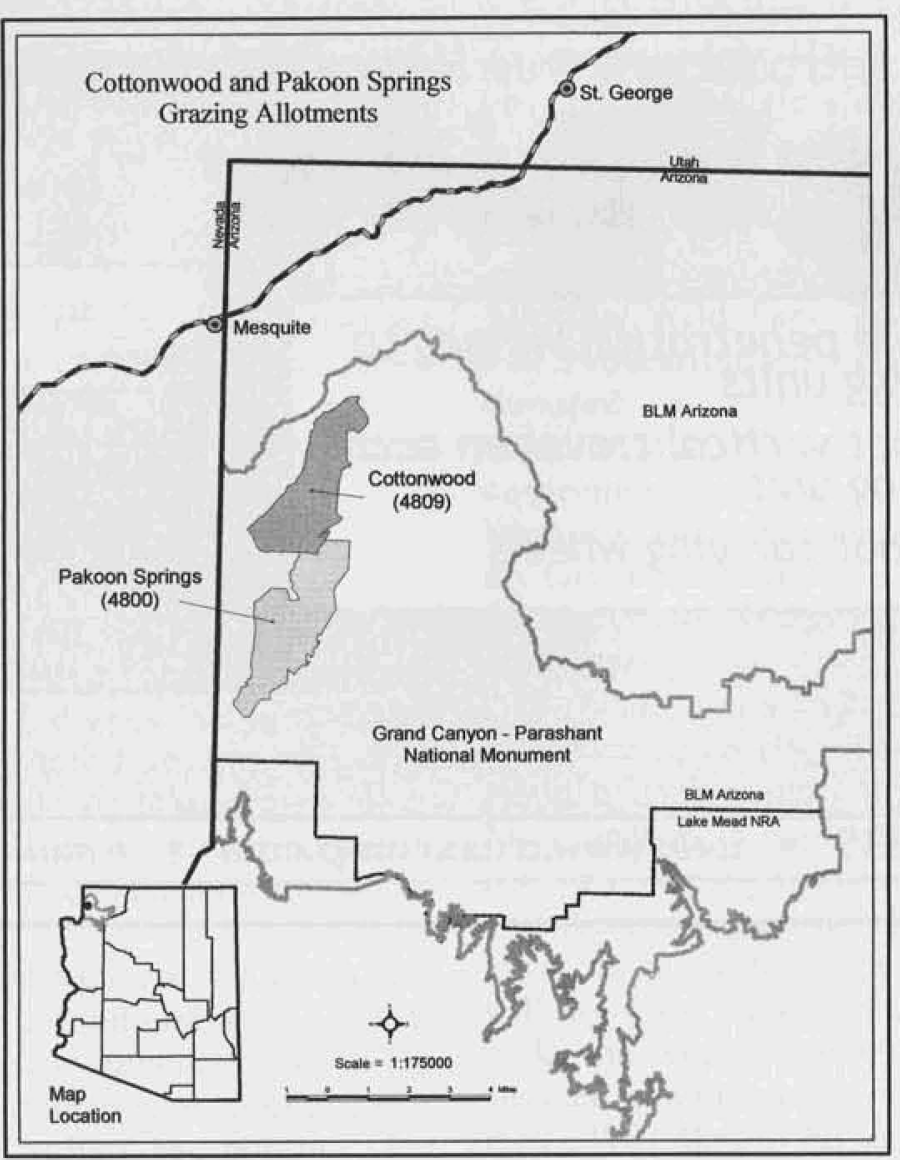

fire-impacted mojave desert of the Arizona Strip, from other areas, indicated the rates of recovery were small to none after $10-15$ years under both season-long grazing or total rest. So, lets look at the details and differences.

\section{The Landscape: Brushy \& Dry}

(See Table 1)

The study areas occur in two allotments - Cottonwood and Pakoon Springs - on the Arizona Strip in Grand CanyonParashant National Monument. The range sites or ecological sites as described by the guides from the National Resource Conservation Service (NRCS). The Lower Cottonwood Wash site is a Sandy Loam, 9-12 inch precipitation zone. The site's plant species composition is described as desert shrub. Its major shrubs are blackbrush, creosotebush, and Joshua trees with a small amount of grass.

The Big Hole and Wayne's Well sites are described as Limy Upland (deep), 6- to 9-inch precip- 
Table 1. The weight based species composition between the sites currently; and what the site guides suggest as species composition for the sites; and Waynes Wells current species composition(in bold), which also is the objective desired for Lower Cottonwood and Big Hole.

Ecological Site

Current and Potential Vegetation

\begin{tabular}{|c|c|c|c|}
\hline Pasture & Lower Cottonwood Wash & Big Hole Pasture & Waynes Well Pasture \\
\hline $\begin{array}{l}\text { Wild Fire History } \\
\text { Ecological Stage }\end{array}$ & $\begin{array}{l}\text { Burned in 1940s } \\
\text { Early Seral } \\
\text { Sandy Loam 9-12" } \\
\text { Precipitation }\end{array}$ & $\begin{array}{l}\text { Burned in } 1979-80 \\
\text { Early Seral } \\
\text { Limy Upland (Deep) } \\
6-9^{\prime \prime} \text { precipitation }\end{array}$ & $\begin{array}{l}\text { Not Burned } \\
\text { Mid-Seral } \\
\text { Limy Upland (Deep) } \\
6-9^{\prime \prime} \text { precipitation }\end{array}$ \\
\hline Current Vegetation* & $\begin{array}{l}\text { Grass:5-14\% } \\
\text { Browse: } 0 \% \\
\text { Shrubs: } 5-12 \% \\
\text { Annuals:73-82\% }\end{array}$ & $\begin{array}{l}\text { Grass: } 15-21 \% \\
\text { Browse: } 2 \% \\
\text { Shrubs: } 2-8 \% \\
\text { Annuals: } 76-79 \%\end{array}$ & $\begin{array}{l}\text { Grass: } 4-41 \% \\
\text { Browse: } 13-17 \% \\
\text { Shrubs: } 33-63 \% \\
\text { Annuals:4-6\% }\end{array}$ \\
\hline
\end{tabular}

*Dry- weight rank based data.

itation zone. The plant species composition is described as creosotebush and white bur sage along with a small presence of grasses.

\section{Precipitation Passes Us By}

When examined in a seasonal context (fall,spring winter, summer), precipitation from 1987 to 1999 showed that $56 \%$ of the seasons were at drought levels and $44 \%$ were at above normal precipitation. Drought was a major player during the period covered in this paper. Precipitation during the droughts ranged from $13 \%$ to $91 \%$, and wet cycles ranged from 111 to $448 \%$ of average precipitation levels according to the precipitation data files of the Arizona Strip Field Office.

\section{The Allotments and Their History}

(See Tables 1 and 2)

During the winter of 1990-91, meetings were held with the permittees, the Arizona Strip Livestock
Grazing Advisory Board, interested publics, and James Bowns, botany and range professor at Southern Utah University. After coordinating with all, BLM decided to remove cattle from Big Hole and Wayne's Well pastures and the cattle were removed from the Cottonwood allotment in 1990 and later reduced for two consecutive grazing seasons, which were shortened to a 4-month use period (as opposed to yearlong) in 1991 and 1992. A year-long restrotation grazing system was implemented on Cottonwood in 1995.

The objectives for the Big Hole and Lower Cottonwood Wash sites were to regain or attain the mid-seral levels like that at Wayne's Well site and as stated in the site guides. Big Hole and Lower Cottonwood Wash sites were and are in the early seral stage.

Fires: The Big Hole pasture burned in 1979 and 1980. This pasture was a blackbrush/ Joshua tree vegetation community. After the fire, it became a plant community dominated by annuals, except in the unburned blackbrush/Joshua tree islands.

As at the Big Hole site, the preburn vegetation on the Cottonwood allotment was blackbrush, creosotebush, and Joshua Trees. Annuals now dominate the Lower Cottonwood Wash of the allotment, but in some areas Joshua trees and other shrubs are returning since burning in the 1940s.

Wayne's Well has never burned and retains a plant community with a balanced diversity of grass, browse, shrubs and forbs.

Drought and Heavy Utilization: During 1988-1990 a drought struck the area. The drought and grazing effects are evident in trend photos 1 and 3 . The precipitation was 73,74 , and $93 \%$ of normal over the three years. Three of the seasons in the three years were only $20-31 \%$ percent of average.

Table 2. A brief on numbers of livestock grazing the allotment and grazing management.

Grazing History of Pastures

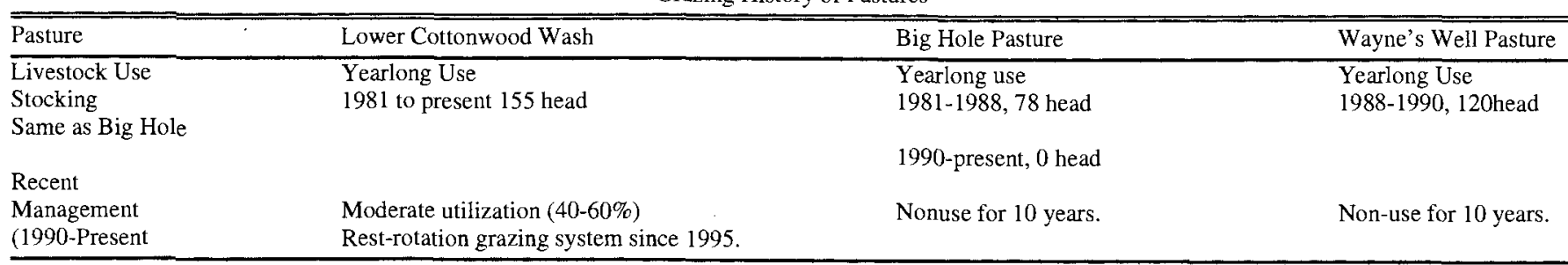




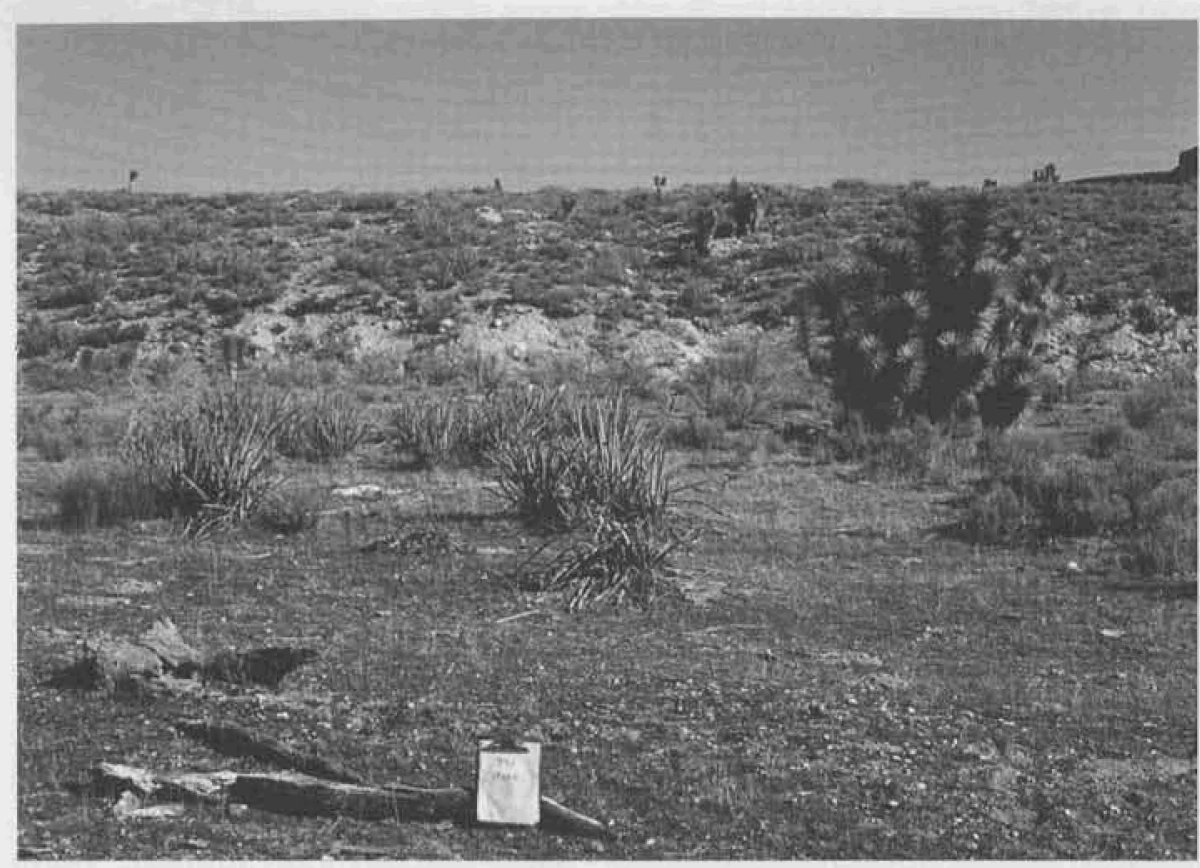

Figure 1. 1988 In drought. Lower Cottonwood Wash Trend Photos.

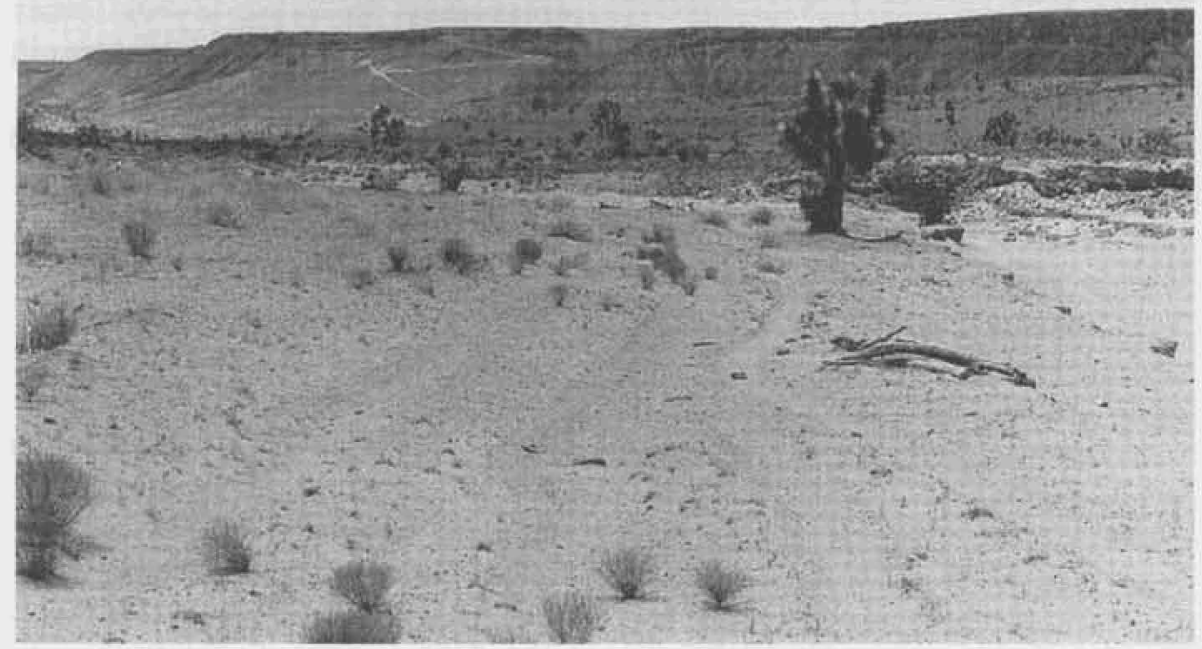

Figure 2. 1989 In drought. Big Hole Trend Photos.

Livestock had heavily used the Lower Cottonwood Wash site for years, which resulted in a major loss of forage. Ranchers on the Pakoon Springs allotments increased to the maximum stocking level at the onset of the drought in 1988 (Table 2). This increase led to condi- early 1980 s. In 1987 , when precipitation was $117 \%$ of normal, Big Hole's utilization reached an average of $53 \%(22-63 \%)$, which was too high. In 1988 average utilization was $70 \%$. In 1989 one reading in the spring showed an average of $59 \%$; a fall reading showed $64 \%$. At the only key area in Cottonwood, a bench area, average utilization in that period was 16 to $39 \%$, which is slight to moderate. However, use in the wash bottom, as shown in the Trend Photo 1, appeared severe. These far-too-high average utilization levels explained the cause of dune formation and the lack of vegetation cover.

\section{The Monitoring Method}

Pace frequency transects, were established in the Pakoon Springs allotment in 1981. One key area had been established in the Big Hole pasture in a heavily grazed and burned area in 1981. Wayne's Well pasture had a transect established in a unburned range site.

The Cottonwood allotment had two transects established and mapped in the $1980 \mathrm{~s}$, but once the rest-rotation system was planned, two more transects were added in the new pastures in 1990-1991. One of these transects was established in Lower Cottonwood Wash in 1990 where it had been heavily grazed. This key area (before it was a key area) had burned in the $1940 \mathrm{~s}$ and had been heavily grazed in all of recent history. The transect was placed in what appeared to be the most trampled and overused area in the pasture.

Key areas, as opposed to inventory transects, were established and mapped to measure vegetation for the effectiveness of the grazing management on the forage species. Generally, the key areas are selected with the influence of livestock waters and are placed about $3 / 4$ of a mile from the water. The transects 


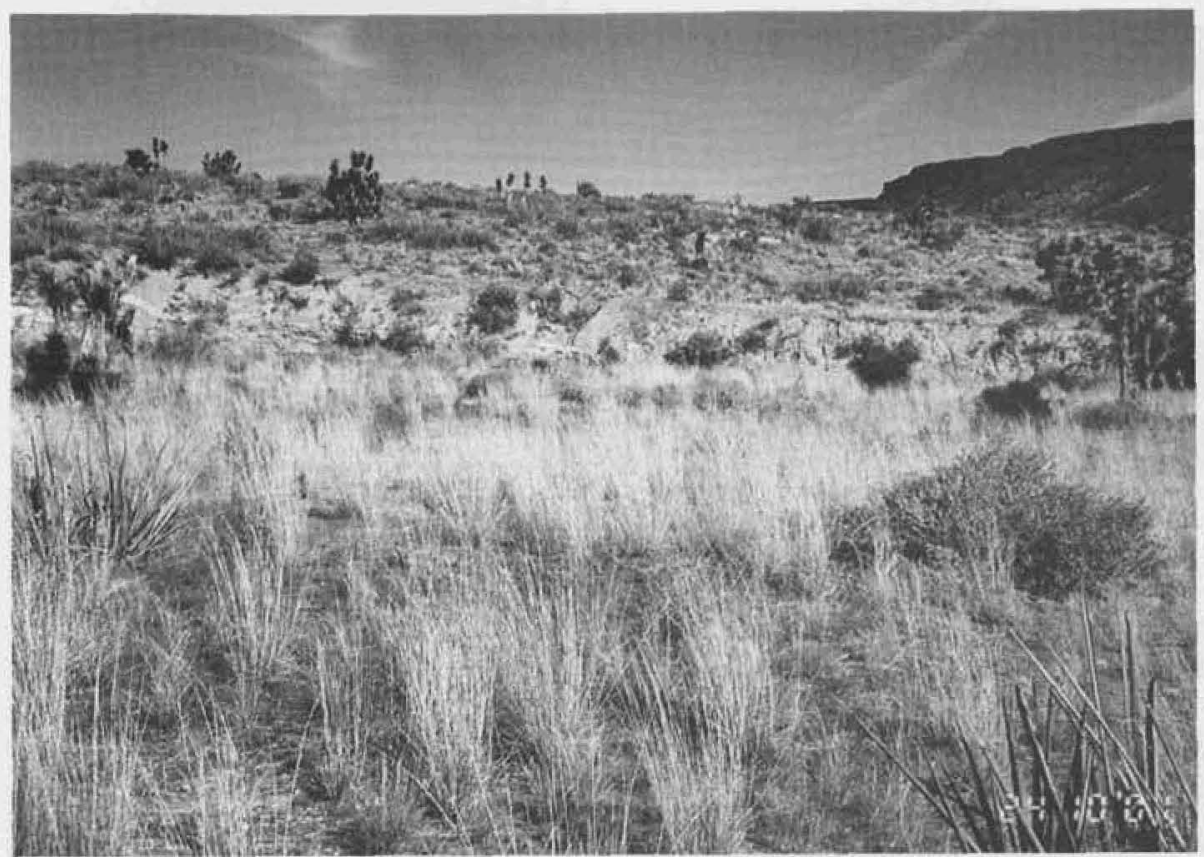

Figure 3. 2001 In recovery after 2000 drought. Lower Cottonwood Wash Trend Photos.

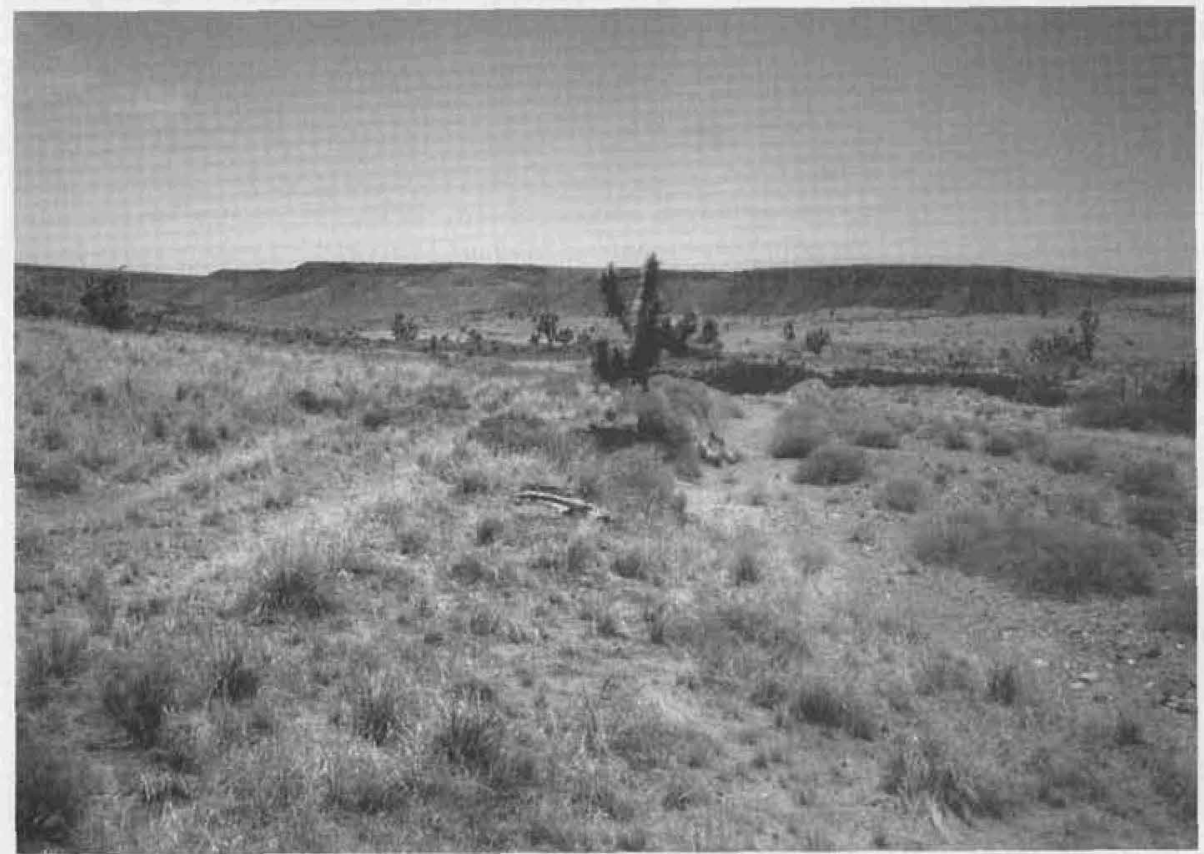

Figure 4. Trend 2001 In Drought and Recovery. Big Hole Trend Photos.

are done with four lines of 50 plots or two lines of 100 plots placed randomly along the line routes. The plot frame is $40 \times 40$ centimeters. Grasses, forbs, annuals, and shrubs that are rooted in the plots are counted. Shrubs with overhanging branches are also counted. The transects in Big in each frequency plot frame are ranked by weight. The heaviest plant is ranked and given a number 7 . The second heaviest is ranked and given a number 2 . The lightest is ranked $l$. The total for the plots is then added up. Each species total is divided by the sum for a species composition, which in the end totals $100 \%$. From these calculations seral stages are determined for the ecological sites.

Utilization transects were also done in the key areas. The key forage species method is used to measure grazing use on each forage species in the key area. Each species is identified, and utilization is estimated for each plant. Photo guides at different use levels on grasses are used as guides. At most transects at least 50 plants are read for each species.

\section{The Results}

Table 1 and 3 presents pace frequency and weight data from the above-described transects in Big Hole's and Wayne's Well Limy Upland 6-9 inch precipitation ecological sites and Lower Cottonwood Wash's Sandy Loam 9-12 inch precipitation ecological sites. Also see trend photos 1 through 4 .

Mesa dropseed, the most frequent warm-season grass, has shown an increase at both the Cottonwood and Big Hole sites, however, the Big Hole site showed a higher frequency. The drought in 2000-01 reduced the dropseed at both key areas. However, there remains more dropseed in Big Hole site than in the Cottonwood site.

Big galleta, another warm season grass, was abundant at the Wayne's Well site and had a low occurrence at both the Big Hole and Cottonwood sites. Big galleta should be at the 1-5\% composition level as stated in the Sandy Loam and Limy Upland site guides. Big galleta occurred at a $11 \%$ frequency 
Table 3 The plant species frequency by categories. The warm-season grasses-mesa dropseed and big galleta-are two of the key grass plants for determining trend towards the seral stages along with various shrub and browse species.

PACE FREQUENCY TREND

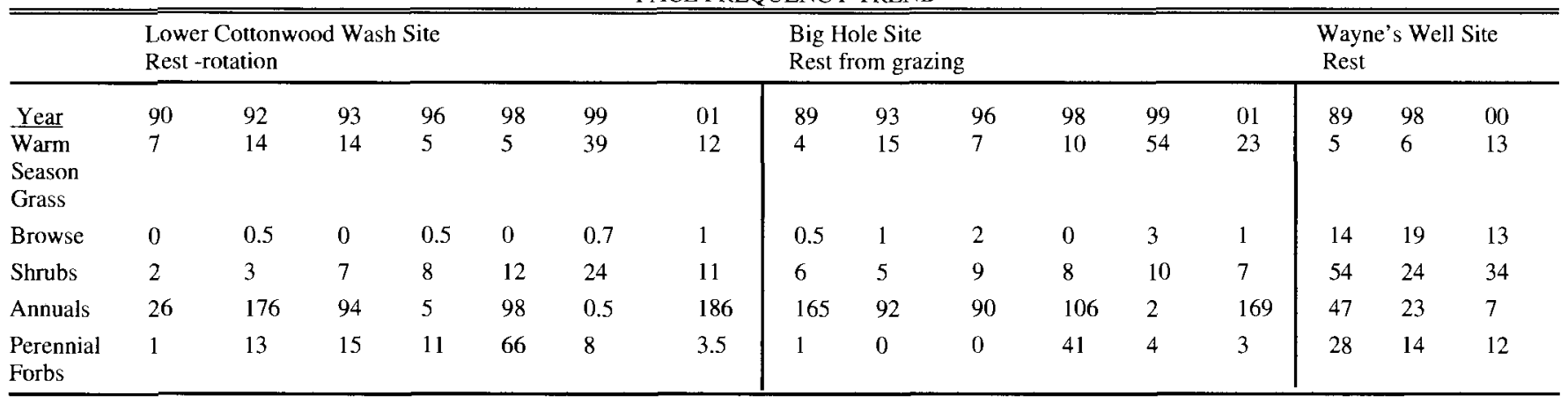

and was at $18 \%$ species composition, on a weight basis, in the Wayne's Well pasture.

Such browse plants as Nevada ephedra, winterfat, and fourwing saltbush were sparse to nonexistent in the key areas in Big Hole and Cottonwood. Browse in Wayne's Well, which consists mostly of Nevada ephedra occurred at above the suggested levels in the site guide. Shrubs, such as creosotebush, bursage, and desert peach occurred frequently in Wayne's Well's site and were at low to no frequency in the Lower Cottonwood Wash and Big Hole sites.

\section{Rest From Grazing Best}

So to what extent can we conclude that rest-rotation grazing and rest from grazing allow the Mojave Desert to recover its perennial grass and browse? Rest from grazing for 10 years seems to be allowing perennial grasses to return at this point in recovery. Mesa dropseed at the Big Hole site and big galleta at the Wayne's Well site have generally increased in frequency. Browse, has shown little to no change in frequency or weight at the key area under 10 years of rest.

Rest-rotation grazing has been in effect for 5 years, after some initial rest and reduced use, in the Lower Cottonwood Pasture. The mesa dropseed does show an up trend. But the mesa dropseed at the Lower Cottonwood site appears to lack as strong an up trend as Big Hole's mesa dropseed. Shrubs seem to be showing a stronger up trend at the Lower Cottonwood site than at the other two sites. Annuals on wet years are abundant at Lower Cottonwood and Big Hole, but are significantly lower at Wayne's Well due to the good perennial plant presence.
Perennial grasses, browse, and shrubs are subtly increasing in the Mojave Desert in the long term. In wet years species will increase dramatically, only to undergo equally dramatic decreases during dry years. But perennial grasses rested from livestock grazing, as opposed to those under rest-rotation grazing with moderate to heavy forage utilization, appear to be undergoing greater increases in frequency and weight during wet years and less of a drop in frequency and weight during dry years.

\section{References}

Bureau of Land Management, 1996. Utilization Studies and Residual Measurement Manual. Denver, Colorado.

Despain, D.W., P.R. Ogden and E.L Smith, 1991. Plant Frequency Sampling (and Dry Weight Rank) for Monitoring Rangelands. Pg 17-21. In G.B. Ruyle (editor)1991. Some Methods for Monitoring Rangelands. University of Arizona. Tucson, Arizona.

United States Department of Agriculture. 1994. Range Site Guide. Field Office Technical Guide.Natural Resources Conservation Service, Fredonia, Arizona. 